\title{
Gangue Utilization Methods Inquiry
}

\author{
Xinghua Li \\ State Key Laboratory of Mine Disaster Prevention and \\ Control, \\ Shandong University of Science and Technology, \\ Qingdao 266590, China \\ 13310671720@126.com
}

\author{
Honghong Wang* \\ College of Resources and Environmental Engineering, \\ Shandong University of Science and Technology, \\ Qingdao 266590, China \\ 15653251832@163.com
}

\author{
Xiaomeng Li \\ College of Mechanical Engineering, \\ Chongqing University, \\ Chongqing, 401331, China \\ lxm2769@126.com
}

\begin{abstract}
In order to reduce the cost of coal, reducing gangue pile, increase the use of coal gangue consumption, the comprehensive utilization of coal gangue, coal is mainly used for power generation, brick, reclaimed farmland, roads, underground filling, construction materials, chemicals and fertilizers, coal gangue brick by exploring the process of improving the heat generated by the cogeneration enable enterprises to get better value for money and bring more social benefits.
\end{abstract}

Keywords-gangue; power; brick; cogeneration; utilization.

\section{INTRODUCTION}

Gangue is mixed in the coal-bearing strata in the rock, in a coal seam associated with the process, a carbon content than coal symbiotic lower than coal black hard rock [1]. Gangue annual emissions equivalent to about $10 \%$ of the coal production of the year, according to incomplete statistics accumulated over the years piled up across the country has a total of about 4.5 billion tons of coal gangue, the larger waste dump over 1600 seats, an area of about 15000 ha, but also to the accumulation amount of 1.5 to 2 million annual rate of increase in emissions is China's largest industrial solid waste currently one [2]. In 2011, China produced about 659 million tons of coal gangue [3], the amount of 450 million tons utilization, comprehensive utilization rate of $70 \%$ [4], the main way for the use of coal gangue power generation, coal gangue brick, coal reclamation of wasteland, roads, underground filling, construction materials, chemicals and fertilizers. gangue have a certain content of coal, long pile spontaneous combustion, and about $1 / 3$ of the spontaneous combustion of coal gangue gangue lot piled pressure not only occupy the land, but also affect the environment, waste rock leaching water contaminated the surrounding soil and groundwater, and gangue contains certain combustible material such as pyrite, spontaneous combustion occurs under appropriate conditions, emissions of sulfur dioxide, hydroxides and soot and other harmful gases, pollution of the atmosphere, nearby residents and asthma patients with chronic bronchitis increased deciduous trees around, the dealer cuts. Fully rational gangue gangue can not only solve their problems themselves brought, can also bring social and economic benefits.

\section{GANGUE APPLICATION STATUS QUO AT HOME AND ABROAD}

In China, from coal mining point of view, each producing 100 million tons of coal per year, about 14 million tons of coal gangue emissions; from coal processing point of view, no washing 100 million tons of coking coal gangue emissions of 2,000 tons per wash 100 million tons of thermal coal, emissions of 15 million tons of waste rock volume [4]. The gangue comprehensive utilization of only $70 \%$. China mainly for power generation, coal gangue brick, coal reclamation farmland, roads, underground filling, construction materials, chemicals and fertilizers. In other countries, mainly Germany gangue utilization measures are: use of wind filled the underground part of the mined-out area, and the other part through the screening process as a building material. In Russia, as in addition to the underground mined-out area of the filling material and for road engineering, production of building materials, but also for more than $20 \%$ organic matter to produce organic gangue mineral fertilizers, crop can stable $15 \%$ to $40 \%$ [5].

\section{UTILIZATION OF THE ADVANTAGES AND DISADVANTAGES OF COAL GANGUE}

According gangue calorific value, carbon content, mineral content is different, you can have different purposes, calorific value at $6.27 \sim 12.54 \mathrm{MJ} \mathrm{kg}$, the carbon content of $>20 \%$ of coal waste suitable for use as boiler fuel; calorific value at $2.09 \sim 6.27 \mathrm{MJ} \mathrm{kg}$, the carbon content of $6 \%$ to $20 \%$ of the gangue suitable for making bricks, cement and other building materials; calorific value of less than $2.09 \mathrm{MJ} \mathrm{kg}$, ash content of $5.0 \%$ to $90 \%$ of the gangue suitable for reclamation, damming and 
paving materials, high organic matter content is also suitable for the production of organic fertilizers.

\section{ADVANTAGES AND DISADVANTAGES OF COAL GANGUE POWER GENERATION}

An important way gangue comprehensive utilization of coal gangue power with that, not only can save a good coal, coal power to ease tensions, but the ash can also produce building materials, eliminating secondary pollution, is a item green project, its social and environmental benefits are very significant. But gangue combustion process, the heat generated less desirable to incorporate part of the high-calorie coal, increasing the cost of business.

\section{ADVANTAGES AND DISADVANTAGES OF COAL GANGUE BRICK}

Slag and fly ash produced after burning coal waste can be used to produce new materials, such as load-bearing and non-load-bearing hollow bricks, aerated concrete, concrete blocks and cement and ceramics and other products. After June 30, 2003, the State 70 cities in the country a total ban on the production and use of solid clay bricks in order to implement the government for bigger offers a rare historic opportunity to strengthen the gangue building materials. Of course, there are still some building materials gangue weak. For example, radioactive substances can not be used in the production of building materials; the high cost of building materials, coal gangue, such as unfavorable for the construction units. But gangue lightweight building materials, heat insulation effect is good, not only to reduce the weight of the building, and is tax-free products, energy-efficient housing construction beneficial.

\section{GANGUE FILLING AND PAVING THE ADVANTAGES AND DISADVANTAGES}

Filling deal gangue most direct, fastest, lowest cost of a comprehensive utilization methods, but also deal with the most traditional methods of coal gangue. Gangue filled mainly refers to fill coal mining subsidence, coal gangue is now also used extensively for road base and meet the principles drawn from the nearest highway construction, but also to protect the mine environment, large-scale application of this technology for the protection of all road construction and mining play a positive role in promoting the use of this method has been long in the North China Plain and Northeast Plain mine. Taking into account the economic efficiency of enterprises, but also to increase per ton of coal mine filling costs 100 yuan, an increase of the company's costs. And pave the way for time-consuming gangue long pile will be spontaneous combustion, post-combustion brittle materials, and water absorption capacity increases, affecting the stability of the grassroots.

\section{THE METHOD UTILIZED TO EXPLORE GANGUE}

Considering the gangue can be used to generate electricity, can also be used, such as brick, brick if the low-temperature waste heat generated in the process is re-used to generate electricity, will greatly reduce the cost of coal, increase profits for enterprises better value for money.

Most gangue brick tunnel kiln. Currently gangue brick tunnel kiln is widely used wide and $6.9 \mathrm{~m}$ wide and $4.6 \mathrm{~m}$ kiln. There is also $9.2 \mathrm{~m}$ or $10.4 \mathrm{~m}$ tunnel kiln, a single output 4.6 wide tunnel kiln is generally 30 million / year 35 million / year, a year in recent years, new large coal gangue brick tunnel kiln production line of about 50/70 . Most of $4.6 \mathrm{~m}$ and $6.9 \mathrm{~m}$ wide tunnel kiln. The kiln is advanced in the industry in line with China's national conditions, technical level of a new furnace.

Gangue brick project in the ultra hot roasting process, resulting in a lot of heat, being directly discharged earlier, only a waste of energy, pollute the environment, do not comply with the relevant national industrial policies. In recent years, some brick baking heat recovery section, mainly through the waste heat boiler output of hot water for heating or to provide bathing water. But the heat utilization is low, in the national energy conservation policy, coal gangue brick companies have tried to use waste heat to generate electricity. Improve energy efficiency and reduce the waste of energy efficiency. Cogeneration significant economic benefits. According to the study, 6 million / year - 10 million / year sinter gangue brick production line. Capacity $1300 \mathrm{kw} \sim 2500 \mathrm{kw}$, although electricity can self-sufficiency. By 0.5 yuan / meter, the annual cost savings 150 yuan to 3 million yuan.(see in the text back)

For gangue brick cogeneration technology, China is still in the development and demonstration phase. Only in August 25, 2008. China's first "gangue brick tunnel kiln waste heat generator test run, well in September and power generation, the technology for the international initiative. But also to fill the gap. Installed capacity of $1500 \mathrm{kw}$. Annually generating more than 790 million degrees, plus savings for enterprises of more than 4 million.

In the October 2008 launch of the "China-United Nations Climate Change Partnership Framework", the evil stone brick coal cogeneration demonstration projects to support the project as one of the key projects for the coal gangue brick-making business to develop a cogeneration technology program and technology demonstration and promotion programs. To improve energy efficiency and reduce air pollution.

\section{CONCLUSION}

The use of coal gangue brick. For more efficient use of resources and energy, and improve the ecological environment of great significance. Currently, gold touch by the crisis, the economic downturn affecting the real estate coal grind stone brick business severely shaped ring, corporate profits declined. Is an opportunity for cogeneration, waste heat power generation companies can improve energy efficiency and reduce business operating costs, reduce coal costs, improve the utilization of coal 
gangue, bring huge economic benefits to the enterprise. The State should put the appropriate policies to encourage enterprises to invest in cogeneration, and to take certain measures to solve the difficult problem of corporate investment.

\section{CORRESPONDING AUTHOR}

Name: Honghong Wang

Number: 15653251832

E-mail: 15653251832@163.com

\section{REFERENCES}

[1] Yanfeng Wang:on Comprehensive Utilization of coal gangue. northern environment.23 (2011),p.52.

[2] ChangJing: gangue comprehensive utilization .Science and Technology Information.(2011).p,35,40.

[3] Shixin Zhang ,Dong Liu ,Fei Shao: and other technology to explore the utilization of coal gangue .Clean Coal Technology. 19 (2013).p, 92-95,122.

[4] Jiaowen Wang; gangue comprehensive utilization status quo analysis. Chinese New Technology and New Products.(2011).p,191

[5] Jie Guan; Practical Learning coal gangue Situation and Prospects. Environment and Sustainable Development. (2011).p,35-37.

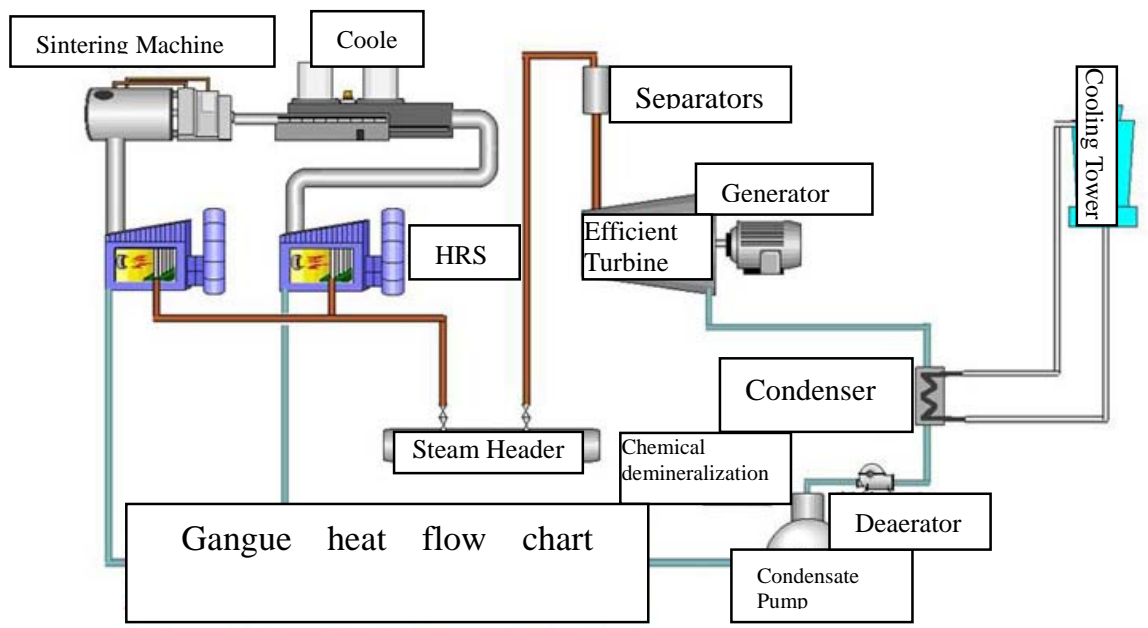

